\title{
USING KANO METHOD TO MEASURE EMPLOYEE SATISFACTION
}

\author{
Shavkat Alimov
}

\begin{abstract}
Employee satisfaction is an important factor for all managers of organization. Most managers undertakes job design without considering various attributes that affects employee satisfaction at workplace. Therefore, it is vital for any organization to know the job attributes that are likely to impact on employee satisfaction. Based on these facts, the researcher undertook this study with an objective analysing how Kano method can be used in measuring employee satisfaction. An extensive literature review on the subject was carried out. The outcome of this study indicated that indeed Kano method can be used in measuring employee satisfaction. The Kano method can be complemented with the Importance Grid Analysis method. The aim of this paper is to analyse literature review of Kano method and its relation to measure employee satisfaction.
\end{abstract}

Keywords: Kano method, employee satisfaction, workforce, literature review, Grid Analysis

\section{INTRODUCTION}

The global competition and the increasing rise in knowledge economy has put emphasis on the importance of Employee satisfaction in the business competition. The willingness to do a good job is chiefly influenced by employee satisfaction. It is imperative to note that satisfied employees have a high motivation to do work, work in an efficient and effective manner (Eskildsen \& Dahlgaard, 2000). Similarly, satisfied employees are more committed to quality and general continuous improvement. Therefore, satisfaction of employees directly influences the quality of a process. Consequently, process quality influences customer satisfaction and the cost quality. Gremler, Bitner and Evans (1994) argues that employees are equal to the company's "internal customers" who needs to be continually satisfied. The satisfaction of employees has always been the key point for researchers. According to Chi and Gursoy (2009), employee satisfaction is one of the major predictor of turnover. Gruban (2010) assert that for successful operation, companies need satisfied employees since employee satisfaction directly translates to the employee commitment to work, honest and consciousness of an employee which in turn reflects on the employee performance. Overall, the significance of employee satisfaction cannot be over emphasized as it directly affects the performance of a firm. This paper will measure employee satisfaction using Kano method because this method prioritizes features which are likely to satisfy employees.

\section{LITERATURE REVIEW}

The current economic situation has forced most enterprises in almost all industries to take each opportunity available to secure their market. The executive of companies in most instances cannot influence the circumstances outside their environment but they can influence situations within the company. Human resource is one of the factors that is important for a company. The questions on how satisfied are the employees with their working conditions, the type of emotional climate one has in the group and the leadership styles are all vital factors. Wright, Dunford and Snell (2001) and Fulmer, Gerhart and Scott (2003) explain that there is a strong association between employee satisfaction and company productivity, customer satisfaction, leadership and the financial outcome of a company. Therefore, this paper will delve on the assessment of employee satisfaction using Kano method. 


\subsection{Employee satisfaction}

According to Cranny, Smith and Stone (1992), employee satisfaction is defined as the combination of affective reactions to the differential perceptions of what they want to receive compared with what they actually receive. The success of an organization and employee satisfaction are directly associated to one another. Presently, the organization managers are faced with the challenge of motivating their work force. The engagement of employee has become a major pillar of success for most companies globally. Employee engagement not only have a huge potential of affecting employee productivity, retention and loyalty but also it is a vital aspect to customer reputation, customer satisfaction and the general value to stakeholders. Each organization aspires to develop an optimum shareholder value which can only be achieved when maximum business performances are achieved which can only be attained when there employee satisfaction. The performance of employees plays a significant part in any company.

\subsection{A review of Kano method}

The Kano model was devised by Dr. Noriaki Kano in the year 1984. The model illustrates the relationship between the performance attribute of a product and its overall impact on customer satisfaction (Kano et al., 1984). In most cases, Kano model is considered as a model of customer satisfaction and a quality model depending on the purpose (Berger, 1993). A customer satisfaction is a process that is on-going and as new demands arise. Moreover, the Kano model employs a questionnaire which consists of a functional and a dysfunctional questions that are useful in retrieving feedback from customers and the feedback is majorly used in the development of a product. The Kano model divides the attributes of products into three major categories as: The threshold, the performance and the excitement (Beng Ang, 1993) as shown below.

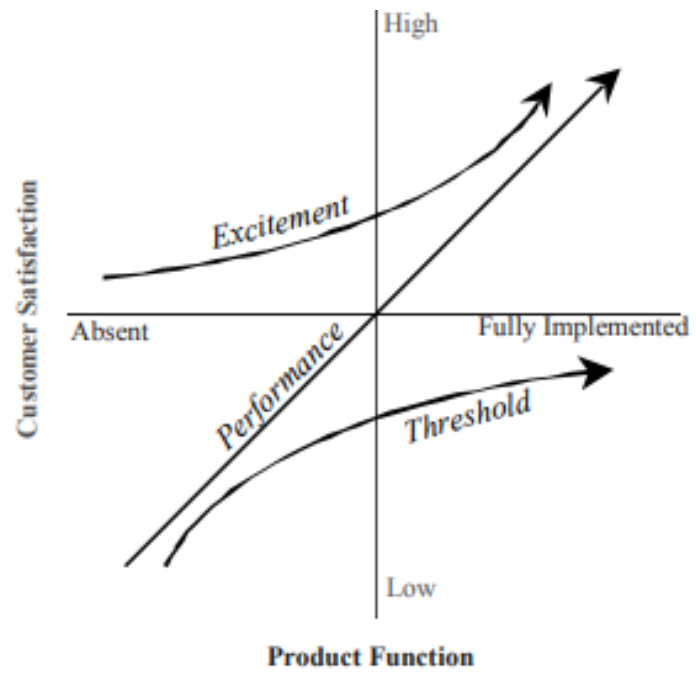

Fig. 1 - Performance and excitement. Source: Beng Ang (1993)

A product that is competitive must be able to meet the basic attributes and be able to optimize the performance attribute (Hartono \& Chuan, 2011). In addition, it must have as many "excitement" attributes as possible but that the market can be able to bear.

Threshold attributes: These are the expected attributes or the "must" be attributes of a product and it does not offer an opportunity for product differentiation. However, lack of these attributes leads to an extreme customer dissatisfaction. A good example is car brakes (Jacobs, 1999).

Performance attributes: These are the functional attributes of a product that will increase customer satisfaction. On the other hand, absence of performance attribute will often lead to 
customer dissatisfaction. The cost at which a customer is willing to pay for a product is in most cases tied to the performance of a product. An example is that customer will be willing to pay more for a vehicle that will offer them a better fuelling economy.

Excitement attributes: These refers to attributes that are unspoken or unexpected attributes by the customer but can lead to a higher level of customer satisfaction. However, absences of these attributes do not lead to customer dissatisfaction. In a competitive environment in which products from different manufacturers provide similar performances, offering excitement attributes can lead to a competitive advantage.

\section{METHODOLOGY}

An extensive literature review on Kano method and its application to employee satisfaction was conducted. More than 20 journals were reviewed but the researcher narrowed down to 15 journals that delved on the Kano methods and its applicability in measuring employee satisfaction. All the journals were chosen from Scopus and Web of Science Database. An importance grid analysis as recommended by Anne and Grønholdt (2001) was adopted for the present study. The importance grid analysis measures attributes such as the explicit important attributes obtainable through direct rating, against the implicit important attributes that is obtainable by regressing attribute performance against the overall measure of employee satisfaction (Mikulić \& Prebežac, 2011). A two-dimension grid having four quadrants can then be constructed bearing the explicit important attributes and the implicit important attributes on the axes. The location of each and every attributes inside the grid reflects the different Kano factors. Low et al. (2015) applied the same method in determining employee satisfaction in Singapore and the results are as follows.

\section{RESULTS}

The outcome from the reviewed literature shows that Kano method can be used in measuring employee satisfaction. Employee are the "internal" customer of any organization and hence Kano method can be applied in measuring their level of satisfaction. A research done by Low et al. (2015) using Kano method to measure employee satisfaction yielded varied results. The researchers constructed the Kano satisfaction coefficient graphs as recommended by Matzler, Fuchs \& Schubert (2004). From their outcome, employee salary appeared to be a onedimensional factor that yielded the highest employee satisfaction if fully fulfilled and the highest employee dissatisfaction if not fulfilled. The courses was found to be an indifferent factor that does not affect employee satisfaction whether it is met or not. Factors such as manpower, flexibility, working hours were found to be attractive features as there is a very high satisfaction when met and a low satisfaction if not achieved.

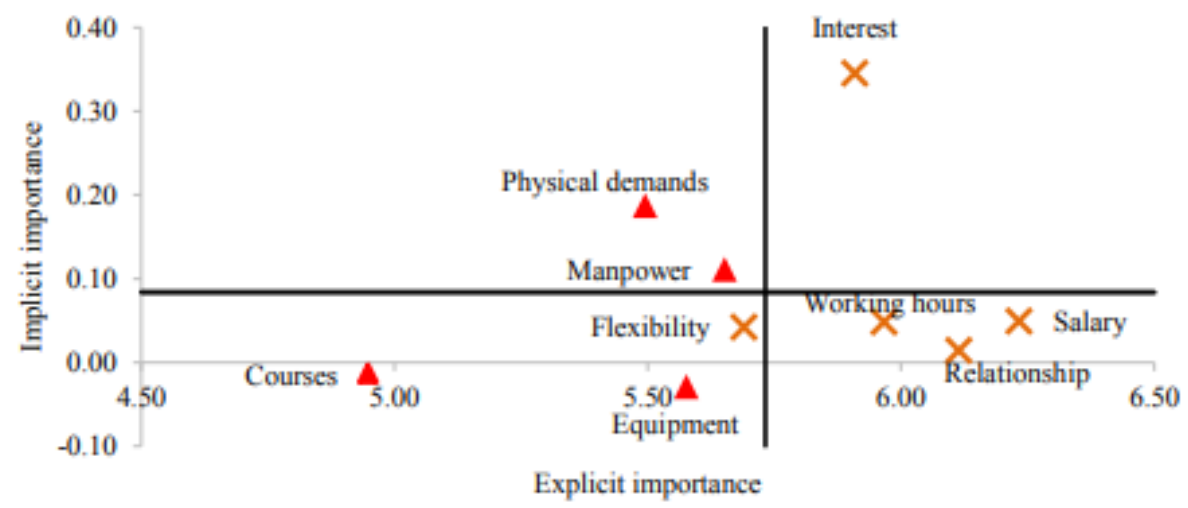

Fig. 2 - Kano satisfaction coefficients. Source: Low et al. (2015) 


\section{CONCLUSION}

In summary, employers can use Kano method in measuring employee satisfaction at their places of work. The outcome from the current study has shown that salaries, manpower, flexibility and working hours are the important factors that affects employee satisfaction. Therefore, the implication of this study is that organization managers and human resource managers should take into consideration these attributes while designing jobs as it affect employee satisfaction which in turn impacts on their performances and the overall organization performance.

\section{References}

Anne, M., \& Grønholdt, L. (2001). Using employee satisfaction measurement to improve people management: An adaptation of Kano's quality types. Total Quality Management, 12(7-8), 949-957. doi: 10.1080/09544120100000020

Beng Ang, K., Tee Goh, C., \& Chye Koh, H. (1993). Research notes, the impact of age on the job satisfaction of accountants. Personnel Review, 22(1), 31-39. doi: $10.1108 / 00483489310025184$

Berger, C. (1993). Kano's methods for understanding customer-defined quality. Center for Quality Management Journal, 2(4), 3-36.

Chi, C. G., \& Gursoy, D. (2009). Employee satisfaction, customer satisfaction, and financial performance: An empirical examination. International Journal of Hospitality Management, 28(2), 245-253. doi: 10.1016/j.ijhm.2008.08.003

Cranny, C. J., Smith, P. C., \& Stone, E. (1992). Job satisfaction: How people feel about their jobs. Personnel Psychology: The Study of People at Work, 46(2), 365-472. doi: 10.1111/j.1744-6570.1993.tb00879.x

Eskildsen, J. K., \& Dahlgaard, J. J. (2000). A causal model for employee satisfaction. Total Quality Management, 11(8), 1081-1094. doi: 10.1080/095441200440340

Fulmer, I. S., Gerhart, B., \& Scott, K. S. (2003). Are the 100 best better? An empirical investigation of the relationship between being a "great place to work" and firm performance. Personnel Psychology, 56(4), 965-993. doi: 10.1111/j.17446570.2003.tb00246.x

Gremler, D. D., Jo Bitner, M., \& Evans, K. R. (1994). The internal service encounter. International Journal of Service Industry Management, 5(2), 34-56. doi: $10.1108 / 09564239410057672$

Gruban, B. (2010). MBO: Management by Objectives or Management by Blaming Others? Retrieved from http://www.dialogos.si/slo/objave/clanki/ciljno-vodenje/

Hartono, M., \& Chuan, T. K. (2011). A proposed integrative framework of Kansei Engineering and Kano model applied to services. Paper presented at The 2nd International Research Symposium in Service Management, Yogyakarta, Indonesia. Yogyakarta: Universitas Pembangunan Nasional. Retrieved from http://repository.ubaya.ac.id/27984/

Jacobs, R. (1999). Evaluating Satisfaction with Media Products and Services: An Attribute Based Approach. European media management review.

Kano, N., Seraku, N., Takahashi, F., \& Tsuji, S. (1984). Attractive Quality and Must-Be Quality. The Journal of the Japanese Society for Quality Control, 14(2), 147-156. doi: 10.20684/quality.14.2_147 
Low, S., Tan, K. C., Peacock, B., Loh, S. K., \& Ping, C. Y. (2015). A proposed Kano-inspired framework applied to job satisfaction for mature Singaporeans. Procedia Manufacturing, 3, 4892-4899. doi: 10.1016/j.promfg.2015.07.619

Matzler, K., Fuchs, M., \& Schubert, A. (2004). Employee satisfaction: does Kano's model apply? Total Quality Management \& Business Excellence, 15(9-10), 1179-1198. doi: 10.1080/1478336042000255569

Mikulić, J., \& Prebežac, D. (2011). Rethinking the importance grid as a research tool for quality managers. Total Quality Management \& Business Excellence, 22(9), 993-1006. doi: 10.1080/14783363.2011.593857

Wright, P. M., Dunford, B. B., \& Snell, S. A. (2001). Human resources and the resource based view of the firm. Journal of Management, 27(6), 701-721. doi: $10.1177 / 014920630102700607$

\section{Contact information}

\section{Shavkat Alimov}

Tomas Bata University in Zlín, Faculty of Management and Economics Mostní 5139, 76001, Zlín, Czech Republic

E-mail: alimov@utb.cz

ORCID: 0000-0001-5118-1663

doi: 10.7441/dokbat.2019.003 